\title{
Perencanaan hutan kota sebagai pengendali kenyamanan termal (studi kasus: Subak Munduk Gendang, Desa Kesiman Kertalangu, Kecamatan Denpasar Timur, Kota Denpasar, Bali)
}

\author{
I Made Dwita Hadi Restyatama1 I G. A. A. Rai Asmiwyati $1^{1^{*}}$, I Gusti Alit Gunadi²
}

1. Prodi Arsitekur Pertamanan, Fakultas Pertanian, Universitas Udayana, Denpasar, Indonesia 80232

2. Prodi Agroekoteknologi, Fakultas Pertanian, Universitas Udayana, Denpasar, Indonesia 80232

*E-mail: asmiwyati@unud.ac.id

\begin{abstract}
Urban forest planning as a thermal comfort controller (case study: Subak Munduk Gendang, Kesiman Kertalangu village, East Denpasar district, Denpasar City, Bali). Urban Forest is a land stretching with dense trees growing in urban areas both on state land and public land, in which is appointed as urban forest by government official authority. One function of the urban forest is to ameliorate microclimate in urban areas so that thermal comfort will increase. The aim of this research is to design urban forest as controller of thermal comfort. This research uses the potential analysis method, site constraints method, amenity method, danger signal method, Thermal Humidity Index (THI), vegetation analysis methods, and linear regression methods. The site of this research is divided into three zone, such as extensive zone, semi intensive zone and intensive zone based on the potential and the constraint of biophysical aspects of the site. The result of this research is on the plan of adding tree green space about $20,53 \%$ or $15610 \mathrm{~m} 2$ of the total area of Subak Munduk Gendang, thereby it is estimated that THI value $<27,00$ (ideal THI 27,00).
\end{abstract}

Keywords: urban forest, urban forest planning, thermal comfort

\section{Pendahuluan}

Pembangunan kota memicu meningkatnya perubahan penggunaan Ruang Terbuka Hijau Kota (RTHK) menjadi lahan-lahan terbangun sehingga berdampak pada penurunan kualitas lingkungan di Kota Denpasar. Penurunan kualitas lingkungan yang paling mudah dirasakan adalah perubahan komponen unsur iklim mikro yaitu peningkatan suhu. Data BMKG (2019) menunjukkan bahwa kenyamanan termal Kota Denpasar masih termasuk kurang nyaman dengan nilai THI 27,7. Pernyataan ini menunjukkan bahwa jika suatu wilayah kota mengalami penurunan lahan tutupan vegetasi, maka akan meningkatkan suhu udaranya serta menurunnya kenyamanan termal.

Menurut penelitian Zal et al., (2017) di Kota Denpasar terdapat daerah rekomendasi prioritas pengembangan RTH yaitu prioritas tinggi, sedang dengan suhu $28^{\circ} \mathrm{C}->30^{\circ} \mathrm{C}$. Daerah rekomendasi prioritas sedang dan daerah rekomendasi prioritas tinggi tersebut banyak ditemui di Kecamatan Denpasar Timur, salah satunya pada Subak Munduk Gendang. Subak Munduk Gendang memiliki nilai kenyamanan termal (THI) 28,8, sehingga memiliki kenyamanan termal yang tidak nyaman. Oleh sebab itu perlu adanya solusi untuk menanggulangi permasalahan tersebut dengan penambahan RTHK. Contoh RTHK sekaligus sebagai ruang terbuka publik untuk menekan penurunan kenyamanan termal di permukiman perkotaan adalah hutan kota. Perencanaan hutan kota sebagai RTHK merupakan cara efektif untuk menurunkan iklim mikro, karena hutan kota memiliki jumlah vegetasi yang mendominasi luas RTH, sehingga dapat meningkatkan kualitas kenyamanan termal lingkungan kota akibat peningkatan suhu. Berdasarkan latar belakang tersebut, penelitian ini bertujuan untuk merencanakan hutan kota sebagai pengendali kenyamanan termal sehingga memberi kondisi termal yang nyaman di area Subak Munduk Gendang dan area disekitarnya serta Kecamatan Denpasar Timur pada umumnya. 


\section{Metode}

\subsection{Lokasi Penelitian}

Penelitian ini dilakukan di Subak Munduk Gendang, Desa Kesiman Kertalangu, Kecamatan Denpasar Timur, Kota Denpasar, Bali (Gambar 1). Penelitian ini dilakukan selama empat bulan yaitu mulai dari bulan Maret 2019 sampai dengan bulan Juni 2019.
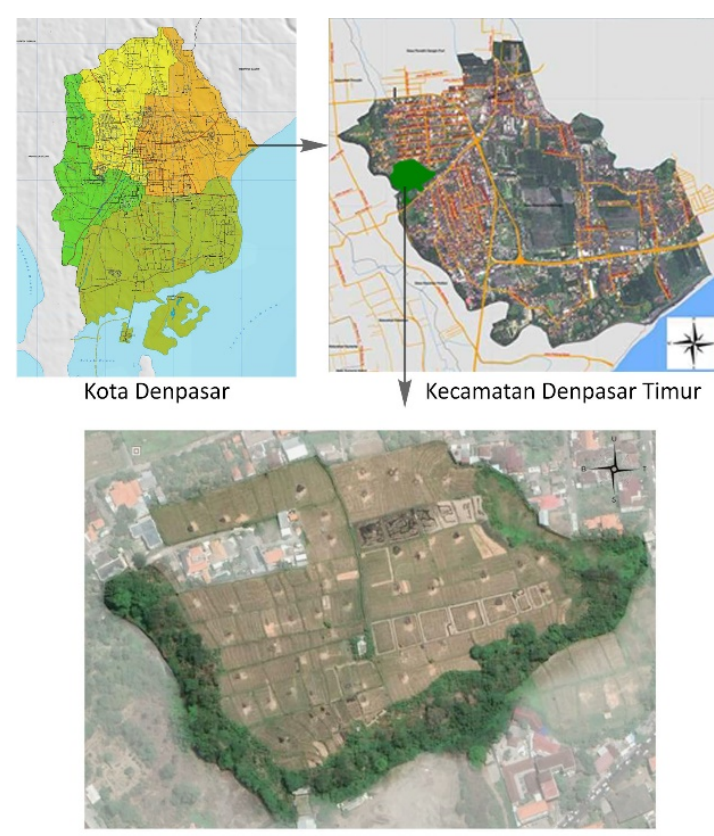

Subak Munduk Gendang

Gambar 1. Lokasi penelitian

\section{$2.2 \quad$ Alat}

Alat yang digunakan dalam penelitian ini adalah laptop, kamera, alat tulis, meteran, Krisbow environment meter kw0600291 dan dibantu dengan perangkat lunak penunjang seperti Adobe photoshop CS6, Sketchup 2015, AutoCad 2015, MS Word 2016, MS Excel 2016, SPSS 20, dan ArcGIS 10.4.

\subsection{Metode Penelitian}

Metode awal yang digunakan dalam penelitian ini adalah metode survei dengan pengumpulan data primer dan sekunder. Tahapan pada penelitian ini yaitu persiapan, inventarisasi, analisis, sintesis dan perencanaan. Metode analisis pada penelitian ini menggunakan metode analisis potensi, kendala tapak, kenyamanan (amenity), ancaman (danger signal), Thermal Humidity Index (THI), metode analisis vegetasi, dan metode analisis regresi linear sederhana. Aspek biofisik dan aspek sosial pada tapak dianalisis dengan mempertimbangkan potensi, kendala, amenity dan danger signal pada tapak. Thermal Humidity Index (THI) digunakan untuk mengetahui tingkat kenyamanan termal pada tapak. Menurut Zahra et al., (2012) indeks kenyamanan dalam kondisi ideal bagi manusia di Indonesia berada pada kisaran THI 19,9-27. Analisis vegetasi digunakan untuk memperoleh informasi kuantitatif tentang struktur dan komposisi suatu komunitas tumbuhan sehingga diketahui data Indeks Nilai Penting (INP) tumbuhan pada tapak (Heddy, 1997). Metode regresi linier digunakan untuk mengukur pengaruh luas RTH pohon terhadap variabel nilai THI, sehingga dapat diketahui berapa luas RTH pohon yang diperlukan untuk memperoleh THI ideal.

\section{Hasil dan Pembahasan}

\subsection{Inventarisasi}

\subsubsection{Aspek Biofisik}

Subak Munduk Gendang terletak di Desa Kesiman Kertalangu, Kecamatan Denpasar Timur, Kota Denpasar, Provinsi Bali. Subak Munduk Gendang memiliki luas total \pm 7,6 Ha atau $76030 \mathrm{~m}$. Area Subak Munduk Gendang terdiri dari area pertanian, jalur hijau, dan area perumahan. Batas wilayah administrasi 
Subak Munduk Gendang, yaitu: sebelah utara: perumahan Jalan Sekar Tujung, sebelah selatan lapangan tembak Bhayangkara Perbakin Bali, SD Saraswati 5, sebelah barat Sungai Ayung, dan sebelah timur perumahan Jalan Sekar Tujung. Suhu tapak pada pagi hari memiliki nilai suhu yang rendah yaitu $27,6-30.9^{\circ} \mathrm{C}$ dengan kelembaban yang memiliki nilai tinggi yaitu $48,6-76,3 \%$. Siang hari pada tapak memiliki suhu yang tinggi yaitu $31,9-36^{\circ} \mathrm{C}$ dengan nilai kelembaban yang rendah yaitu $37,8-61.2 \%$. Area tapak pada waktu sore hari memiliki suhu kembali relatif rendah yaitu $30,8-33,1^{\circ} \mathrm{C}$ dengan nilai kelembaban yang tinggi, yaitu 56 - 75,8\% (Gambar 2). Menurut Nurisjah (2015) suhu, kelembaban dan angin merupakan faktor iklim utama yang harus dikelola dengan baik karena akan mempengaruhi kenyamanan dan aktifitas manusia.

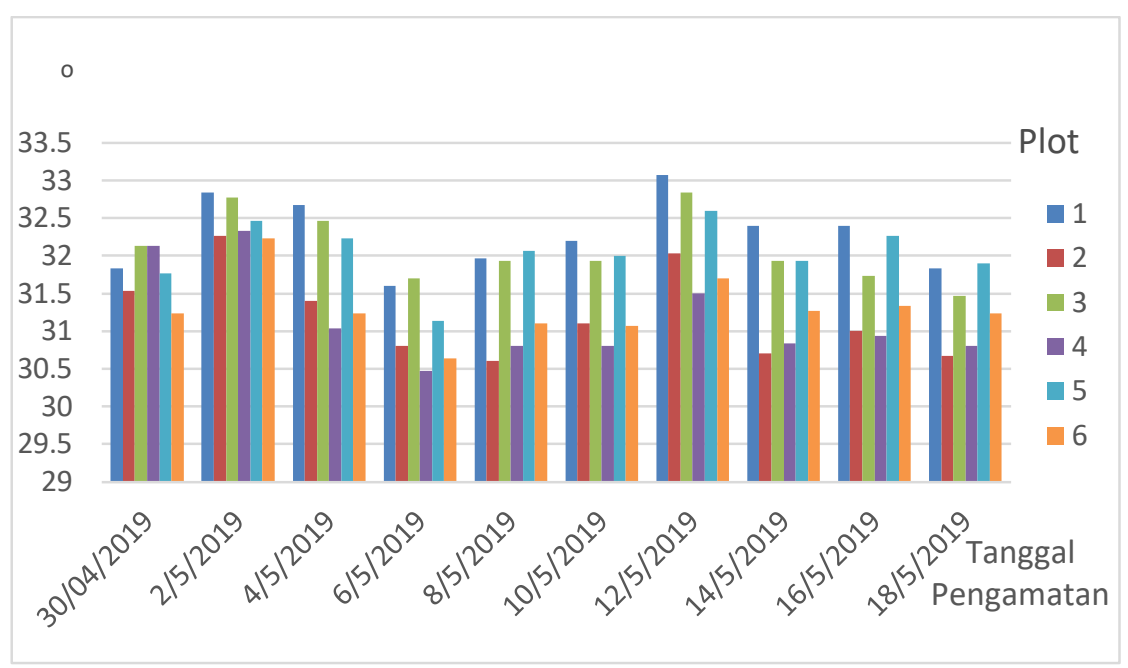

Gambar 2. Suhu rata-rata Subak Munduk Gendang

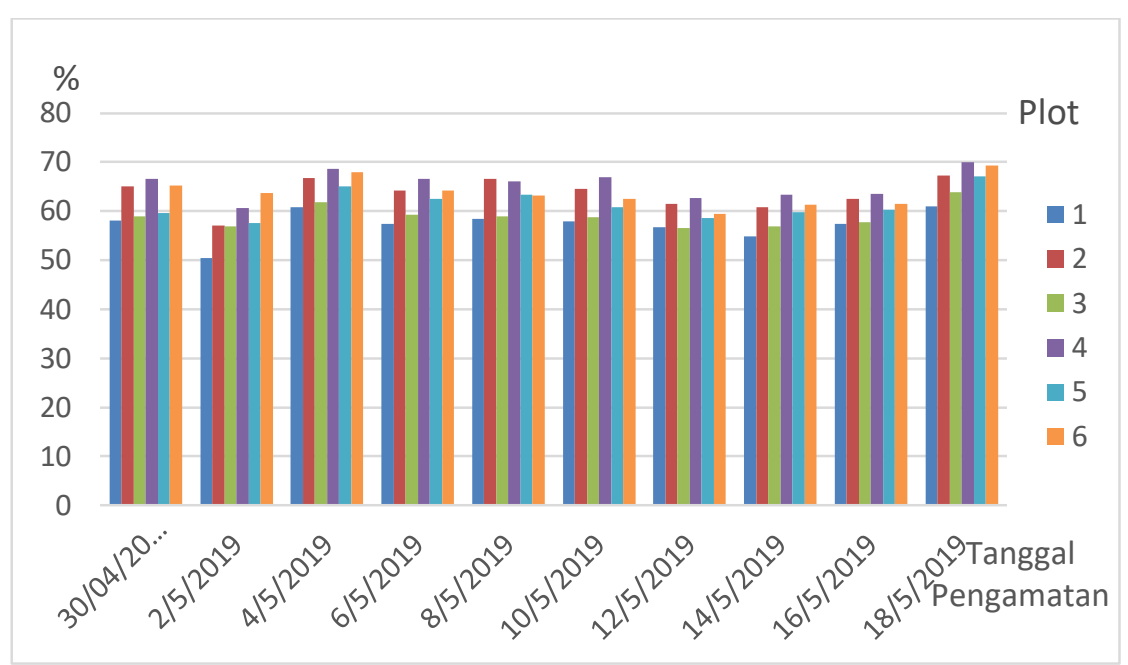

Gambar 3. Kelembaban rata-rata Subak Munduk Gendang

Kecepatan angin maksimum (WX) di Kecamatan Denpasar Timur berkisar 6-13 knot, dan rata-rata kecepatan angin (WAV) berkisar 2-10 knot. Rata-rata arah angin pada saat kecepatan maksimum (WD) adalah $115.5^{\circ}$ yang berarti angin bertiup dari arah sekitar arah antara tenggara dan selatan. Rata-rata arah angin terbanyak (WDX) di Kecamatan Denpasar Timur adalah 106,40 yang berarti angin bertiup dari arah antara timur dan tenggara. Berdasarkan vegetasi yang ditemukan pada tapak area jalur hijau terdiri dari tanaman bertipe pohon, perdu, semak dan tanaman penutup tanah (groundcover) yang bervariasi dan memiliki kerapatan vegetasi yang padat, sedangkan pada area pertanian terdiri atas tanaman bertipe pohon, perdu, 
semak dan tanaman penutup tanah (grouncover) yang tidak terlalu bervariasi, didominasi oleh tanaman pertanian, serta memiliki kerapatan vegetasi pohon yang renggang.

Berdasarkan hasil observasi di lokasi, satwa yang ada pada tapak terdiri atas insekta, aves dan reptil. Satwa- satwa yang ditemui antara lain capung (Pantala flavescens), belalang (Dissosteira carolina), walang sangit (Leptocorisa oratoria), kadal kebun (Eutropis multifasciata), katak (Fejervarya cancrivora), burung gereja (Passer montanus), burung pipit (Lonchura molucca), tikus (Rattus argentiventer). Elevasi terendah berada di area jalur hijau dengan penutupan vegetasi pohon, perdu, semak, dan groundcover. Sebaliknya elevasi tertinggi berada area pertanian berupa area persawahan. Kemiringan lahan landai pada tapak penelitian ditemukan pada area pertanian dengan kemiringan lahan bervariasi antara 1,6\% - 8,3\%. Kemiringan curam ditrmukan pada area jalur hijau bagian barat dan selatan memiliki kemiringan lahan bervariasi antara 20\% $80 \%$. Area jalur hijau sebelah timur memiliki kemiringan lahan landai dan agak curam yaitu $10 \%-25 \%$. Subak Munduk Gendang didominasi oleh jenis tanah Inceptisol dan Mollisol dengan luas masing-masing 14442,63 $\mathrm{Ha}$, dan $63716,11 \mathrm{Ha}$. Tanah Inceptisol dan Mollisol yang memiliki tingkat kesuburan yang cukup tinggi sehingga cukup baik untuk ditanami vegetasi. Sumber air pada tapak penelitian berasal dari sungai ailran Sungai Ayung. Drainase pada area pertanian berupa parit berukuran $40 \mathrm{~cm}-60 \mathrm{~cm}$. Drainase pada area jalur hijau berupa aliran air dari area pertanian, Sungai Ayung di sebelah barat, dan aliran anak Sungai Ayung di bagian selatan.

\subsubsection{Aspek Sosial}

Penggunaan lahan di sekitar Subak Munduk Gendang dimanfaatkan sebagai area pemukiman, area pendidikan, serta area lapangan tembak. Area pemukiman yaitu perumahan Jalan Sekar Tujung yang terletak di sebelah utara dan timur tapak, area selatan pada tapak terdapat Sekolah Dasar Saraswati 5 Denpasar, dan Lapangan Tembak Bhayangkara Perbakin Bali, sedangkan area barat pada tapak adalah Sungai Ayung dan area jalur hijau. Tapak yang terletak dekat dengan area pemukiman dan pendidikan, menyebabkan tapak sering dikunjungi oleh warga sekitar untuk beraktivitas. Data peraturan pemerintah dalam perencanaan hutan kota ini adalah Peraturan Pemerintah Republik Indonesia Nomor 63 Tahun 2002 Tentang Hutan Kota, Ranperda Rencana Tata Ruang Wilayah Kota Tahun 2008 - 2027 yang memuat data perencanaan hutan kota di Kota Denpasar.

\subsection{Analisis}

\subsubsection{Thermal Humidity Index (THI)}

Rata-rata nilai THI paling rendah tercatat di areal hijau pada waktu pagi hari dengan nilai THI yaitu 27,31 , sedangkan nilai rata-rata $\mathrm{THI}$ tertinggi tercatat di area perumahan pada waktu siang hari dengan nilai THI 30,90. Hal ini menunjukkan bahwa nilai THI pada pagi hari lebih rendah jika dibandingkan pada siang dan sore hari, sehingga pada pagi hari kondisi termasuk lebih nyaman. Nilai rata-rata THI keseluruhan Subak Munduk Gendang adalah 28,8. Nilai THI Subak Munduk Gendang jika dibandingkan dengan nilai THI rata-rata kota Denpasar, nilai THI pada tapak memiliki nilai lebih tinggi dibanding nilai THI rata-rata kota Denpasar. Nilai rata-rata THI Kota Denpasar adalah 27,7, sedangkan nilai THI rata-rata Subak Munduk Gendang adalah 28,8.

\subsubsection{Analisis Vegetasi}

Vegetasi yang terdapat pada tapak diambil pada area jalur hijau. Area jalur hijau terdiri dari tanaman non-produksi dan tanaman produksi. Berdasarkan pengambilan data, tanaman non-produksi mendominasi vegetasi pohon pada tapak. Hal ini dapat dilihat dari sebaran kepuh (Sterculia foetida) dengan nilai INP 35,51\%, tutup beling (Mallotus mollissimus) dengan nilai INP 31,61\%, lamtoro (Leucaena leucocephala) dengan nilai INP 24,44\%, dan angsana (Pterocarpus indicus) dengan nilai INP 24,23\%. Tanaman produksi pohon pada area jalur hijau didominasi oleh jati (Tectona grandis) dengan nilai INP 17,92\%, nangka (Artocarpus heterophyllus) dengan nilai INP 28,70\%, enau (Arenga pinata) dengan nilai INP 17,26\%, kelapa (Cocos nucifera) dengan nilai INP 16,00\%, mangga (Mangifera indica) 19,05\%. Tapak penelitian dengan tutupan vegetasi pohon rapat terdapat pada area jalur hijau sebelah barat. Pada area pertanian tanaman didominasi oleh oleh tanaman produksi. Hal ini dapat dilihat dari sebaran padi (Oryza sativa), pacar air (Impatiens balsamina), ketela pohon (Manihot esculenta), pisang (Musa sp), tebu (Saccharum officinarum) yang cukup mendominasi tapak penelitian. Pada area pertanian juga terdapat vegetasi pohon dan perdu yang bukan merupakan tanaman produksi, yaitu: kedondong hutan (Spondias pinnata) sebanyak 45 pohon, turi (Sesbania 
grandiflora) sebanyak 3 pohon, waru (Hibiscus tiliaceus) sebanyak 2 pohon, gamal (Gliricidia sepium) sebanyak 20 pohon, jati cina (Senna alexandrina) sebanyak 5 pohon, dan kembang telang (Clitoria ternatea) sebanyak satu pohon.

\subsubsection{Analisis Regresi Linear Sederhana}

Berdasarkan hasil pengambilan data penutupan lahan diketahui RTH pohon di Subak Munduk Gendang meliputi 27,38 \% (X) dari luas wilayah, sedangkan nilai THI pada tapak adalah 28,8 (Y). Agar dapat mengukur perbandingan RTH pohon dengan THI pada SPSS 20, maka area tapak dibagi menjadi dua bagian yaitu area timur dan area barat, sehingga diketahui luas RTH pohon dan THI masing-masing area (Tabel 1).

Berdasarkan nilai $x$ dan $y$ tersebut maka diperoleh persamaan $y=-0,089 x+31,269$. Dari persamaan tersebut diketahui bahwa setiap penambahan 1\% RTH pada tapak berpengaruh terhadap nilai THI harian sebesar $-0,089$. Perencanaan RTH pohon pada tapak dapat diperkirakan berdasarkan $y=0,089 x+31,269$ untuk menurunkan THI menjadi 27,00 (THI ideal). Maka diperlukan penambahan RTH pohon sebesar $20.22 \%$ dari total luas wilayah atau sebesar 15373,3 m2 untuk mencapai kondisi kenyamanan ideal (THI 27,00).

Tabel 1. Nilai $x$ dan $y$ area timur dan barat

\begin{tabular}{ccccc}
\hline Area & Luas Area $\left(\mathrm{m}^{2}\right)$ & Luas RTH Pohon $\left(\mathrm{m}^{2}\right)$ & $\mathrm{X}(\% \mathrm{RTH}$ Pohon $)$ & THI \\
\hline Timur & 35890 & 9595 & 26.73 & 28.9 \\
Barat & 40140 & 11220 & 28 & 28.8 \\
\hline
\end{tabular}

\subsubsection{Analisis potensi, kendala tapak, amenity, ancaman (danger signal)}

Luas Subak Munduk Gendang memenuhi syarat luas minimal lahan yang diperuntukan untuk area hutan kota yaitu 0,25 Ha serta memenuhi syarat untuk menurunkan iklim mikro sehingga dapat sebagai pengendali kenyamanan termal dengan luas minimal yaitu $4000 \mathrm{~m}^{2}$ yang diatur dalam Peraturan Pemerintah Nomor 63 Tahun 2002. Selain itu area Subak Munduk Gendang berdasarkan Ranperda Rencana Tata Ruang Wilayah Kota Tahun 2008 - 2027 direncanakan sebagai area hutan kota. Hasil dari pengambilan data pada tapak akan dijabarkan dalam peta yang memiliki tiga pembagian area yaitu zona ekstensif, zona semi intensif dan zona intensif. Zona ekstensif atau zona lindung yang merupakan zona yang sangat peka secara fisik dan ekologis dari berbagai gangguan, zona semi intensif yang merupakan zona yang agak peka akan gangguan manusia, dan zona intensif yang merupakan zona yang tidak peka terhadap berbagai aktifitas manusia, serta memiliki daya dukung pengunjung yang tinggi.

Berdasarkan hasil pengambilan data, dapat dijabarkan dalam peta yang memiliki lima pembagian area berdasarkan tingkat nilai THI. Nilai THI 28,5 adalah THI paling nyaman pada tapak, memiliki densitas pohon sangat tinggi, sangat peka secara fisik dan ekologis dari berbagai gangguan, oleh karena itu pada area ini dijadikan area menyuplai kenyamanan termal pada tapak sehingga dapat direncanakan sebagai zona ekstensif. Area THI 28,6 adalah area yang memiliki tingkat kenyamanan yang hampir mirip dengan area sebelumnya sehingga dapat dijadikan sebagai zona semi intensif yang memiliki aktivitas pengunjung yang bersifat pasif dan sedikit atau dijadikan zona ekstensif yang tidak terdapat aktivitas pengunjung. Area THI 29 juga dapat dijadikan sebagai zona semi intensif karena dapat menjadi pembatas antara zona ekstensif dan zona intensif, walaupun memiliki nilai THI kurang nyaman, hal tersebut dapat diatasi dengan penambahan vegetasi pohon. Area THI 29,1 tidak peka terhadap berbagai aktifitas sehingga dapat dijadikan sebagai zona intensif yang memiliki tingkat aktivitas yang tinggi (Gambar 4). Walaupun pada area ini juga memiliki nilai THI kurang nyaman, hal tersebut dapat diatasi dengan penambahan vegetasi pohon. 


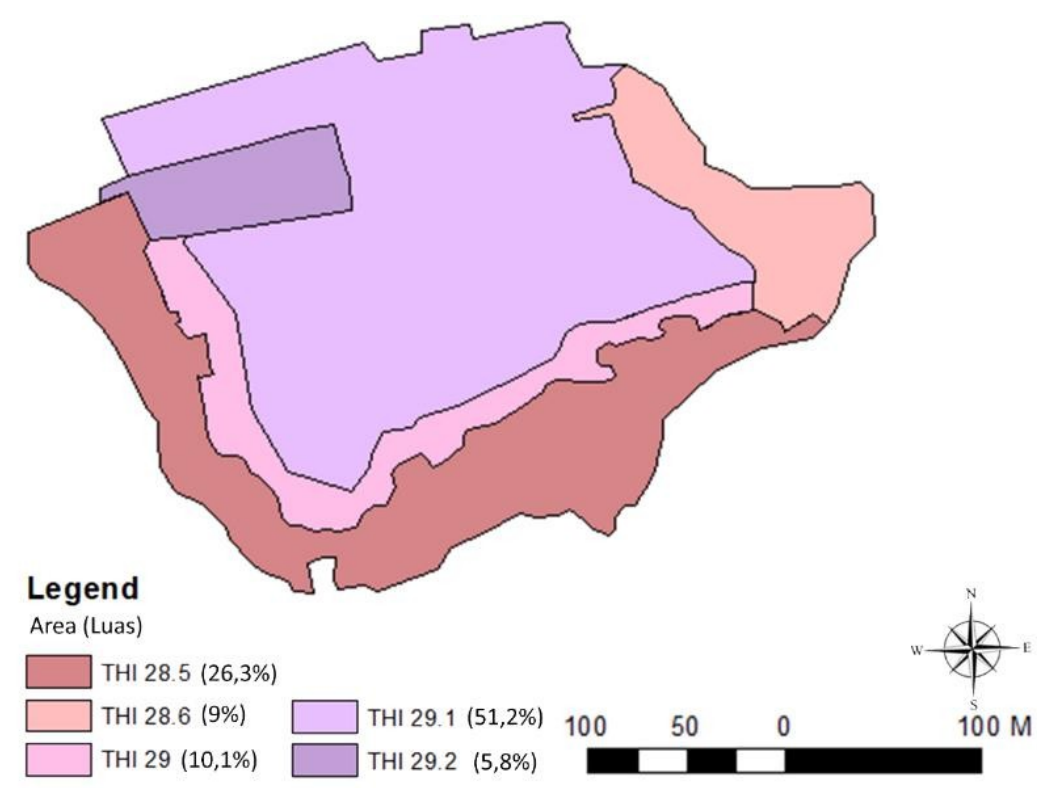

Gambar 4. THI Subak Munduk Gendang

Berdasarkan hasil pengambilan data, dapat dijabarkan dalam peta yang memiliki tiga pembagian area berdasarkan kerapatan vegetasi yaitu zona ekstensif, zona semi intensif dan zona intensif. Area kerapatan vegetasi tinggi dapat direncanakan sebagai area ekstensif, karena area ini memiliki densitas pohon yang tinggi dan harus dilindungi agar kerapatan vegetasi pada area tersebut tetap dapat terjaga, sehingga dapat menjadi penyuplai utama keyamanan termal. Area kerapatan vegetasi sedang dapat direncanakan sebagai area semi intensif yang memilki aktivitas yang rendah dan bersifat pasif, sehingga dapat menjaga kerapatan vegetasi pada tapak. Area kerapatan vegetasi rendah dapat direncanakan sebagai zona intensif yang memiliki tingkat aktivitas yang tinggi serta zona semi intensif yang berfungsi sebagai pembatas antara zona ekstensif dengan zona intensif (Gambar 5).

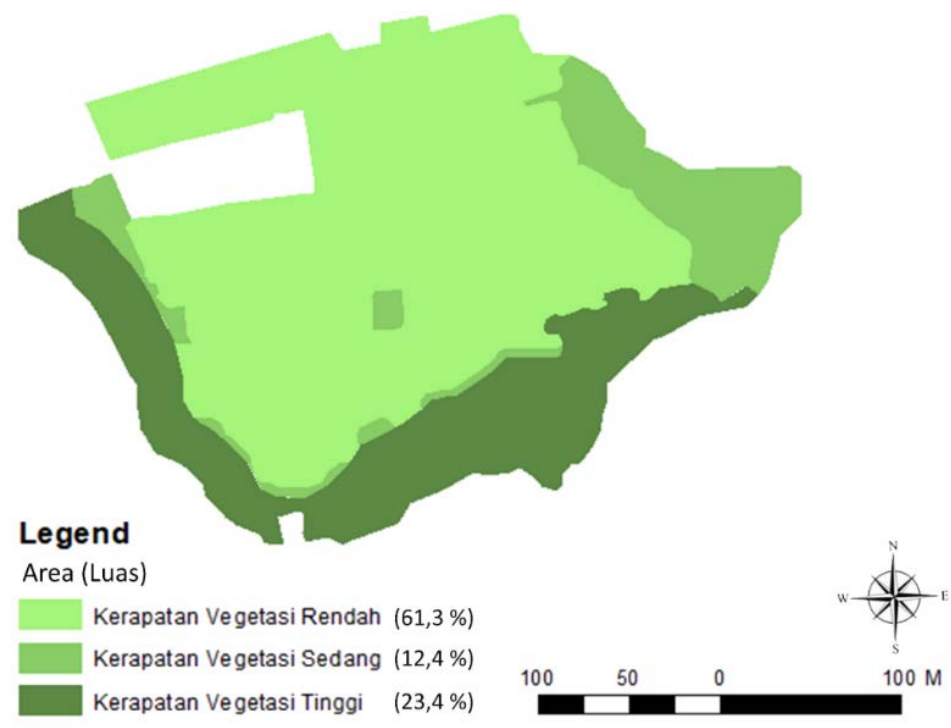

Gambar 5. Kerapatan Vegetasi Subak Munduk Gendang 
Berdasarkan hasil pengambilan data, dapat dijabarkan dalam peta yang memiliki tiga pembagian area berdasarkan kemiringan topografi pada tapak yaitu zona ekstensif, zona semi intensif dan zona intensif. Area curam dan sangat curam dapat direncanakan sebagai zona ekstensif, karena memiliki kemiringan lahan yang sangat curam, sehingga berbahaya bagi aktivitas pengunjung. Area agak curam dapat direncanakan sebagai zona semi intensif karena memiliki kemiringan lahan yang agak landai, sehingga bisa terdapat berbagai aktivitas pengunjung yang bersifat pasif dan terbatas. Area datar dan landai dapat direncanakan sebagai zona semi intensif dan zona intensif, karena memiliki kemiringan lahan yang landai sehngga memungkinkan terdapat berbagai aktivitas pengunjung (Gambar 6).

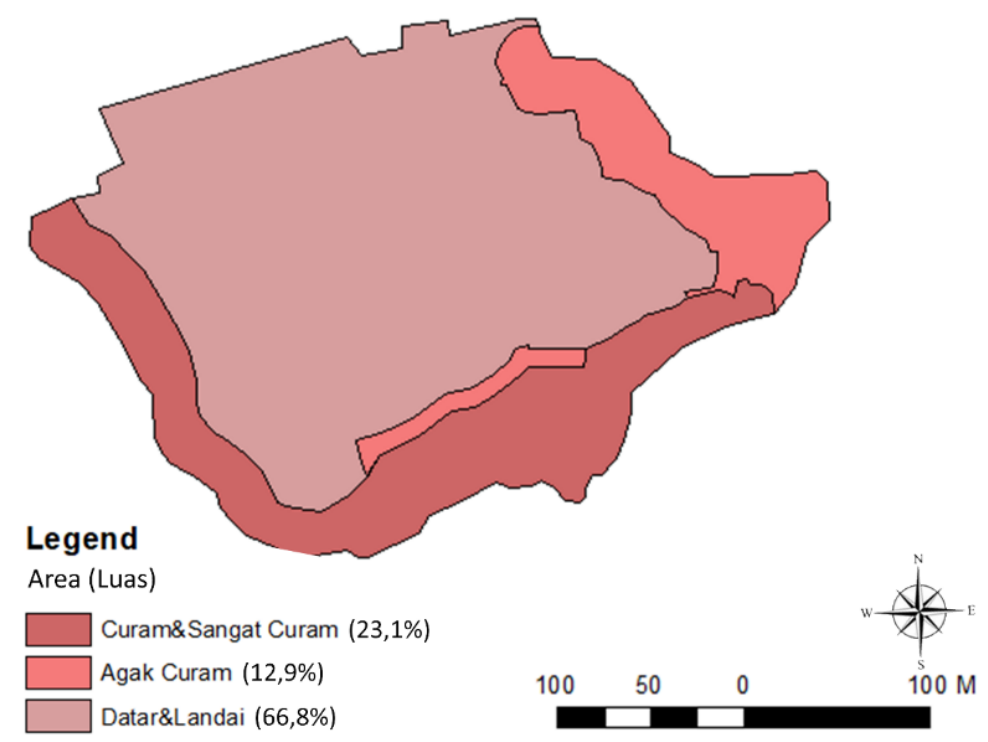

Gambar 6. Kemiringan lahan Subak Munduk Gendang

Tanah inceptisol pada tapak terdapat dalam posisi yang curam atau lembah dengan kemiringan lereng, sehingga memenyebabkan tanah inceptisol memiliki potensi terhadap erosi. Oleh sebab itu, area pada tanah inceptisol dapat direncanakan sebagai zona ekstensif. Molisol merupakan jenis tanah yang tahan terhadap erosi, kerena dalam pembentukannya terdapat penyebaran akar-akar ke profil tanah, sehingga dapat direncanakan sebagai zona semi intensif dan intensif yang memiliki aktivitas pengunjung (Gambar 7).

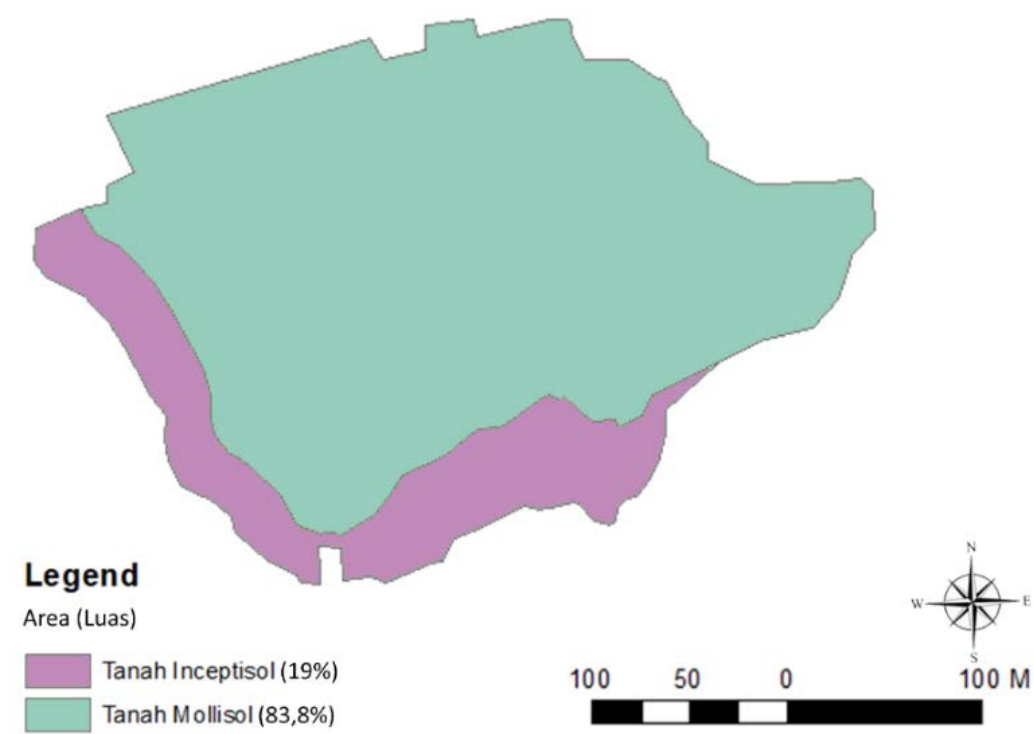

Gambar 7. Jenis tanah Subak Munduk Gendang 
Tapak sekitar Subak Munduk Gendang dimanfaatkan sebagai area pemukiman, area pendidikan, serta area lapangan tembak. Tapak Subak Munduk Gendang terletak dekat dengan pemukiman yaitu perumahan Jalan Sekar Tujung dan Sekolah Dasar Saraswati 5 Denpasar, sehingga tapak sering dikunjungi oleh warga sekitar untuk beraktivitas. Hal tersebut dapat dimanfaatkan untuk membuat berbagai fungsi aktifitas seperti rekreasi dan edukasi. Area sekitar Subak Munduk Gendang juga terdapat lapangan tembak yang berjarak cukup dekat dari tapak yang bisa berdampak buruk kepada pengguna disekitar tapak. Hal tersebut dapat diatasi dengan memanfaatkan areal tersebut sebagai zona ekstensif yang tidak terdapat aktifitas pengunjung. Selain itu dapat dilakukan penambahan pengkerasan tembok setinggi $\pm 4 \mathrm{~m}$ pada area yang dekat dengan jangkauan arah tembak, sehingga dapat mencegah pengunjung terkena tembakan peluru.

\subsection{Konsep dan Perencanaan Lanskap}

\subsubsection{Konsep ruang dan aktivitas}

Konsep ruang direncanakan menjadi tiga zona utama yang dikembangkan dalam area hutan kota, yaitu zona ekstensif, zona semi intensif dan zona intensif (Gambar 8). Zona ekstensif atau zona lindung yang merupakan zona yang sangat peka secara fisik dan ekologis dari berbagai gangguan. Zona ini sangat dibatasi atau tidak boleh sekali memilki aktivitas pengunjung, kecuali untuk kegiatan penelitilian atau aktivitas khusus lainnya. Zona ini dimanfaatkan sebagai fungsi ekologis dengan vegetasi pada tapak ini berperan paling besar sebagai pengendali kenyamanan termal. Fasilitas pendukung yang dapat disediakan pada zona eksentif berupa fasilitas yang terkait dengan aktivitas konservasi maupun fasilitas yang terkait dengan aktivitas khusus, seperti: fasilitas terkait informasi, edukasi, dan sirkulasi.

Zona semi intensif yang merupakan zona yang agak peka akan gangguan manusia. Zona ini dapat dimanfaatkan untuk berbagai aktifitas rekreasi warga kota yang bertipe alam, pasif dan tidak mengganggu sumber daya alam yang tersedia. Fasilitas yang dapat dikembangkan berupa fasilitas pelayanan umum karena terbatasnya aktivitas pada zona ini. Fasilitas berupa: tempat sampah, fasilitas terkait informasi, edukasi, sirkulasi dan lain sebagainya.

Zona intensif yang merupakan zona yang tidak peka terhadap berbagai aktifitas manusia, serta memiliki daya dukung pengunjung yang tinggi. Zona intensif dapat dimanfaatkan untuk berbagai macam aktifitas pengunjung yang dapat memaksimalkan fungsi sosial yang bersifat aktif seperti berolahraga, rekreasi, edukasi. Fasilitas yang dapat disediakan berupa fasilitas pendukung aktivitas pengunjung maupun fasilitas pengelolaan yang terkait dengan pelayanan pengunjung, seperti: fasilitas jogging track, tempat parkir, toilet, tempat sampah, tempat duduk, fasilitas terkait informasi, edukasi, sirkulasi dan lain sebagainya.

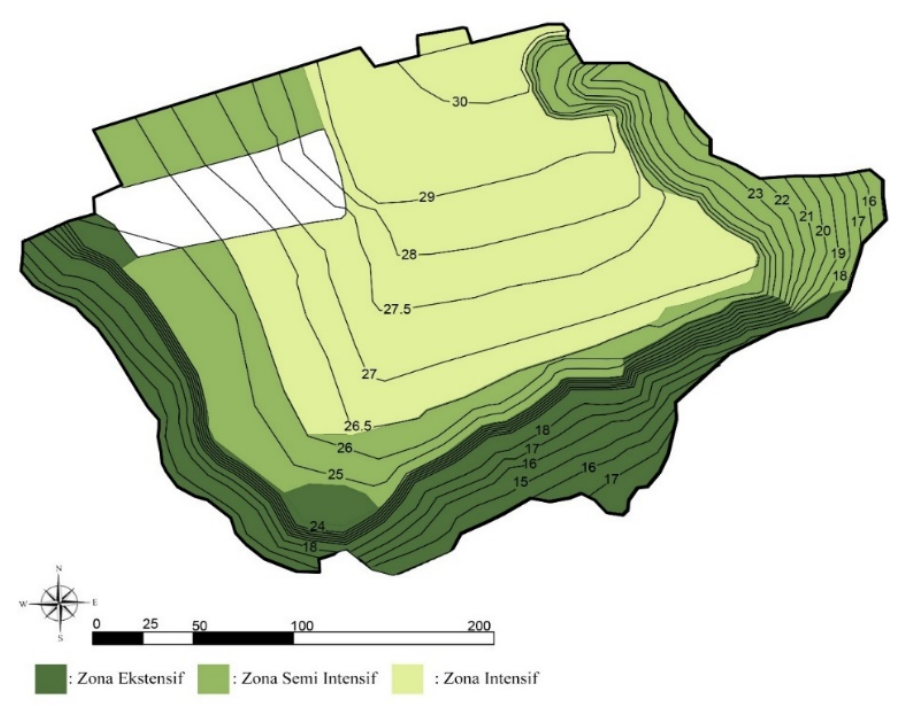

Gambar 8. Konsep ruang 


\subsubsection{Konsep sirkulasi}

Konsep sirkulasi yang akan diterapkan dalam tapak secara umum terdiri atas dua sirkulasi yaitu jalur sirkulasi utama, dan jalur sirkulasi sekunder (Gambar 9). Jalur sirkulasi utama yaitu jalur yang ditujukan untuk pejalan kaki yang dapat dilewati oleh lebih dari satu pejalan kaki. Jalur sirkulasi sekunder adalah jalur berperan sebagai sirkulasi dalam zona di area hutan kota. Jalur ini ditata secara alami dengan lebar 0,8m - 1m yang dapat dilewati oleh satu pejalan kaki.

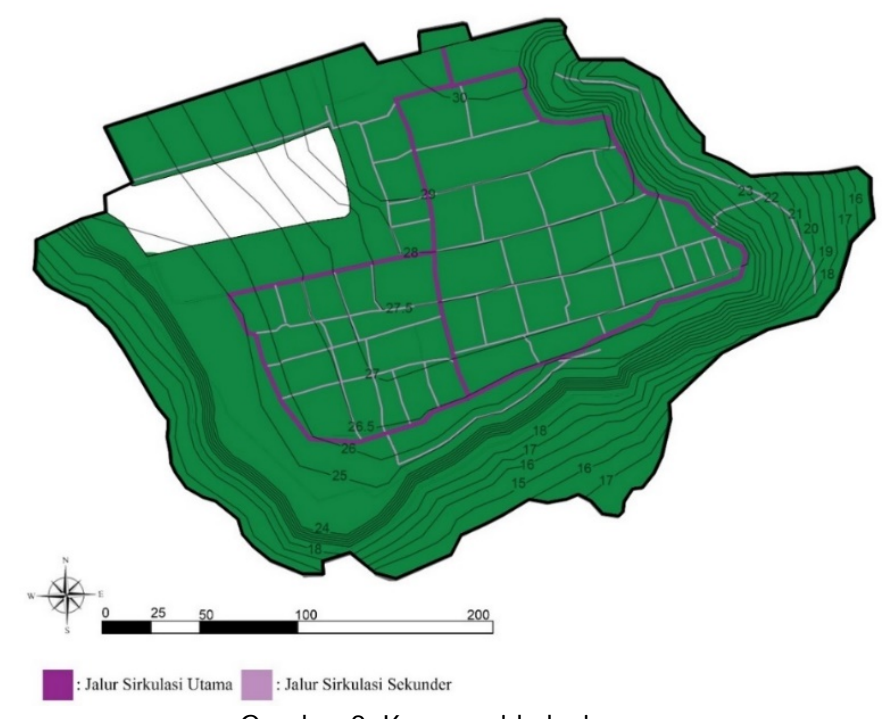

Gambar 9. Konsep sirkulasi

\subsubsection{Konsep Vegetasi}

Konsep vegetasi sebagai pengendali kenyamanan termal ini akan berdasarkan pada aspek bentuk hutan kota, struktur hutan kota, dan karakteristik tanaman. Bentuk hutan kota yang dapat dikembangkan pada tapak sebagai pengendali kenyamanan termal adalah hutan kota bentuk menyebar, yaitu tidak mempunyai pola tertentu dengan komunitas vegetasi tumbuh menyebar terpencar (acak) dalam bentuk rumpun atau kelompok-kelompok pohon dalam area berukuran kecil (Nurisjah, 2015). Konsep vegetasi ini menggunakan tipe hutan kota berstrata banyak yaitu komunitas tumbuh-tumbuhan hutan kota selain terdiri dari pepohonan dan rumput juga terdapat perdu, semak, terna, liana epifit, ditumbuhi banyak anakan dan penutup tanah, jarak tanam rapat tidak beraturan dengan strata, serta komposisi mengarah meniru komunitas tumbuh-tumbuhan hutan alam (IIwan, 1994). Konsep vegetasi berdasarkan fungsi tanaman terdiri dari tanaman konservasi dan tanaman penunjang. Tanaman konservasi berfungsi mengendalikan kenyamanan termal. Secara umum karakteristik tanaman yang dipilih adalah efektif mengontrol radiasi matahari dengan pohon sebagai tanaman utama, pemanfaatan perdu, semak dan ground cover membentuk strata guna efektif mengontrol radiasi, menurunkan suhu, meningkatkan kelembaban serta mengarahkan angin. Karakteristik tanaman pohon peneduh yang digunakan yaitu memiliki tajuk lebar dan kerapatan daun tinggi serta ketinggian kanopi lebih dari dua meter. Tanaman konservasi bertipe pohon seperti: Ficus virens, Ficus racemose, dan Tamarindus indica. Tanaman penunjang terdiri dari tanaman non konservasi, seperti pohon, perdu, semak, dan rumput (ground cover) yang dapat menunjang kenyamanan pengunjung dan mendukung fungsi hutan kota. Tanaman penunjang memiliki fungsi estetika dan fungsi sosial. Berdasarkan analisis vegetasi, tanaman yang memiliki kondisi baik dan menunjang fungsi hutan kota akan dipertahankan sebaliknya tanaman yang tidak sesuai dengan fungsi diganti dengan tanaman yang baru. 


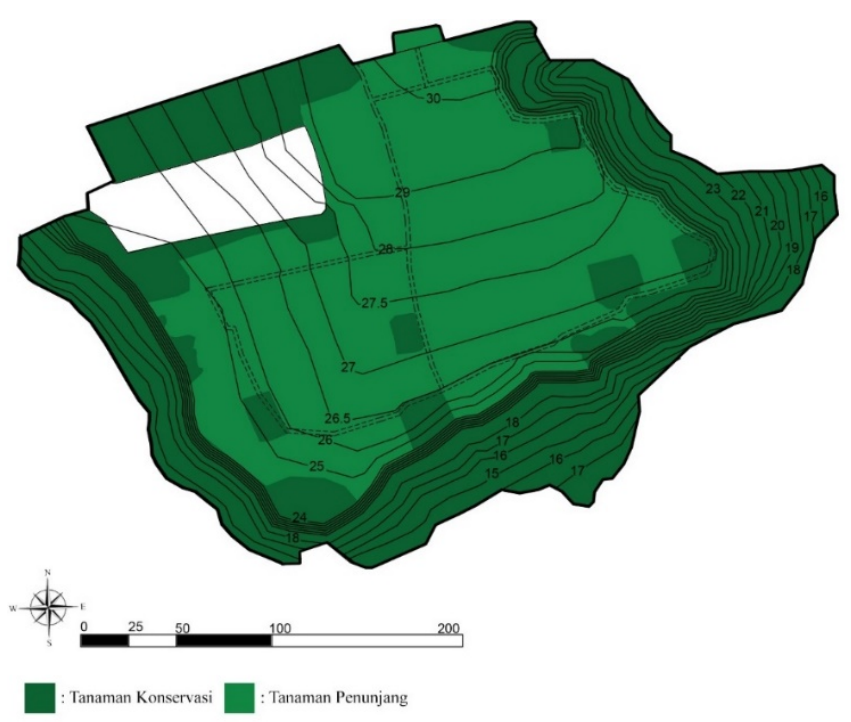

\subsection{Site Plan}

Gambar 10. Konsep vegetasi

Perencanaan induk lanskap direncanakan penambahan RTH pohon sebesar 20,53\% atau $15610 \mathrm{~m}^{2}$, sehingga diperkirakan nilai $\mathrm{THI}<27,00$. Pada musim hujan jumlah ini dapat menurun karena hutan kota berbentuk menyebar strata banyak mampu menurunkan suhu 2,28\%, dan meningkatkan kelembaban sebesar 4,79\% (Irwan, 1994). Perencanaan hutan kota juga berpengaruh terhadap kenyamanan termal di lingkungan sekitarnya. Penelitian Tauhid (2008) menunjukan bahwa vegetasi pohon pada jarak $24 \mathrm{~m}$ dari hutan kota, suhu udara meningkat $0,40{ }^{\circ} \mathrm{C}-1,44{ }^{\circ} \mathrm{C}$, sehingga nilai THI diperkirakan masih ideal.

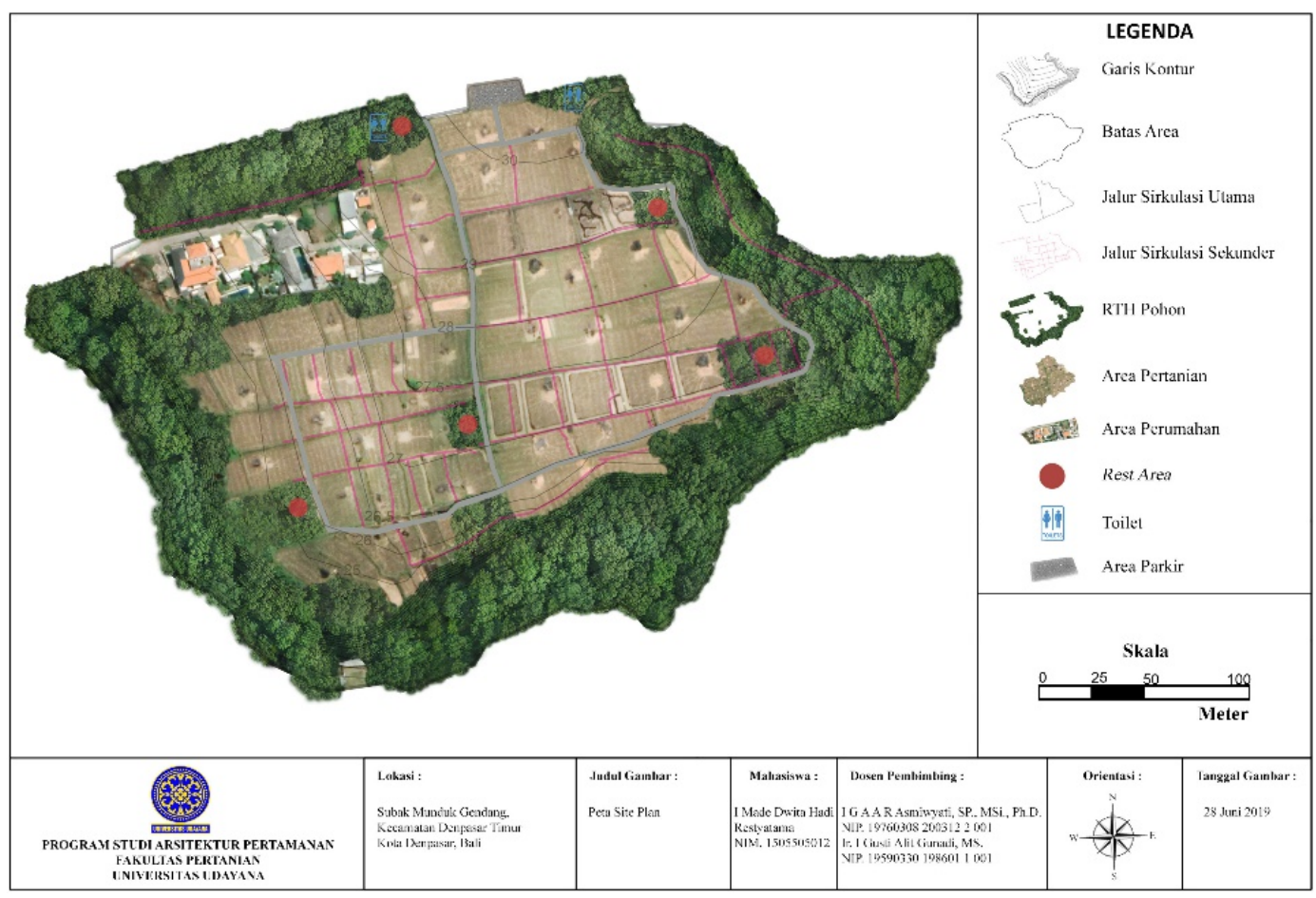

Gambar 11. Site plan hutan kota 


\section{Simpulan dan Saran \\ 4.1 Simpulan}

Tapak penelitian memiliki luas \pm 7,6 Ha yang memenuhi syarat luas minimal lahan yang diperuntukan untuk area hutan kota $(0,25 \mathrm{Ha})$ serta memenuhi syarat luas minimal untuk menurunkan iklim mikro sehingga dapat sebagai pengendali kenyamanan termal $\left(4000 \mathrm{~m}^{2}\right)$. Nilai rata-rata THI keseluruhan Subak Munduk Gendang adalah 28,8, sehingga nilai THI masuk dalam kondisi kurang nyaman. Perencanaan tapak pada penelitian ini adalah mengangkat konsep hutan kota sebagai pengendali kenyamanan termal. Area hutan kota terbagi menjadi tiga zona, yaitu zona ekstensif, zona semi intensi, dan zona intensif.

Tapak Subak Munduk Gendang memerlukan penambahan RTH pohon sebesar $20.22 \%$ dari total luas wilayah atau sebesar 15373,3 m2 untuk mencapai kondisi kenyamanan ideal (THI 27,00). Perencanaan induk lanskap direncanakan penambahan RTH pohon sebesar 20,53\% atau $15610 \mathrm{~m}^{2}$, sehingga diperkirakan nilai $\mathrm{THI}<27,00$. Pada musim hujan jumlah ini dapat menurun karena hutan kota berbentuk menyebar strata banyak mampu menurunkan suhu 2,28\%, dan meningkatkan kelembaban sebesar 4,79\% (Irwan, 1994). Perencanaan hutan kota juga berpengaruh terhadap kenyamanan termal di lingkungan sekitarnya. Penelitian Tauhid (2008) menunjukkan bahwa adanya vegetasi pohon mengakibatkan meningkatnya suhu hanya 0,40 ${ }^{\circ} \mathrm{C}-1,44{ }^{\circ} \mathrm{C}$ pada jarak sampai $24 \mathrm{~m}$. Hal tersebut menunjukkan bahwa pada jarak $24 \mathrm{~m}$ dari hutan kota, suhu udara meningkat $0,40{ }^{\circ} \mathrm{C}-1,44{ }^{\circ} \mathrm{C}$, sehingga nilai THI diperkirakan masih ideal.

\subsection{Saran}

Penelitian ini menghasilkan alternatif rencana hutan kota yang dapat digunakan sebagai acuan pemikiran dan pertimbangan dalam pengembangan kawasan hutan kota, khususnya sebagai pengendali kenyamanan termal pada Kota Denpasar ataupun di kawasan lain yang memiliki karakteristik lanskap dataran rendah dan topografi yang bervariasi. Penelitian ini juga menunjukan perlunya penambahan RTHK di Kota Denpasar karena nilai THI masih tergolong kurang ideal. Pengembangan perencanaan hutan kota Denpasar sesuai RTRW Kota Denpasar perlu diperhatikan karena dapat dijadikan solusi terhadap kenyamanan termal yang belum ideal. Penelitain ini juga bersifat studi kasus, sehingga perlu dianalisis kembali penerapannya pada lokasi lain.

\section{Daftar Pustaka}

Balai Besar Meteorologi Klimatologi dan Geofisika Wilayah III Denpasar. (2019) Data Unsur Iklim Bulanan. Pelayanan Jasa Informasi Klimatologi.

Heddy, S. (1997). Metode Analisis Vegetasi dan Komunitas. Bogor: Penerbit Institut Pertanian Bogor.

Irwan, Z. D. (1994). Peranan Bentuk dan Struktur Kota terhadap Kualitas Lingkungan Kota. Diakses dari Institut Pertanian Bogor, IPB Repository, http://repository.ipb.ac.id/handle/123456789/2576.

Nurisjah, S. (2015). Hutan Kota Perencanaan Praktis. Jakarta: Ikatan Arsitek Lansekap Indonesia (IALI).

Republik Indonesia. (2002). Peraturan Pemerintah Republik Indonesia Nomor 63 Tahun 2002 Tentang Hutan Kota. Jakarta: Sekretaris Negara Republik Indonesia.

Tauhid., Khadiyanto, P., Hadiyarto, A. (2008). Kajian Jarak Jangkau Efek Vegetasi Pohon Terhadap Suhu Udara Pada Siang Hari di Perkotaan (Studi Kasus: Area Simpang Lima Kota Semarang). Diakses dari Universitas Diponegoro, Institutional Repository (UNDIP-IR), http://eprints. undip.ac.id/17888/.

Zahra, A. F., Sitawati., \& Suryanto, A. (2012). Evaluasi Keindahan dan Kenyamanan Ruang Terbuka Hijau (RTH) Alun-Alun Kota Batu. Diakses dari Universitas Brawijaya, Jurnal Produksi Tanaman, http://protan.studentjournal.ub.ac.id/index.php/protan/article/view/140.

Zal, M. A., Nuarsa, I. W., \& Utami, N. W. F. (2017). Analisis Korelasi Perubahan Tutupan Vegetasi terhadap Perubahan Suhu Udara di Kota Denpasar. Diakses dari Universitas Udayana, Open Journal Systems UNUD, https://ojs. unud.ac.id/index.php/ECOTROPHIC/article/view/35441. 